\title{
静岡・清水海岸全域を対象とした海浜変形予測 \\ Prediction of Topographic Changes along Shizuoka and Shimizu Coasts
}

\author{
宇多高明 ${ }^{1} \cdot$ 大橋則和 $^{2} \cdot$ 岩本仁志 $^{3} \cdot$ 宮原志帆 $^{4} \cdot$ 芹沢真澄 $^{5} \cdot$ 石川仁憲 $^{6}$ \\ Takaaki UDA, Norikazu OHASHI, Hitoshi IWAMOTO, Shiho MIYAHARA \\ Masumi SERIZAWA and Toshinori ISHIKAWA
}

\begin{abstract}
Long-term topographic changes since 1968 along the entire Shizuoka and Shimuzu coasts with a $17 \mathrm{~km}$ stretch extending between the Abe River mouth and the tip of the Mihono-matsubara sand spit were reproduced using the contour-linechange model. Beach erosion of these coasts was triggered by the decrease in sediment supply from the Abe River due to excessive riverbed mining until 1967. After 1982/83 natural sand supply of the river increased and accretion occurred on these coasts. Measured topographic changes were reproduced using the contour-line-change model considering grain size change. Not only the movement of sand body but also the shoreline and bathymetric changes were numerically reproduced. The calculated results were in good agreement with the measured topographic changes.
\end{abstract}

\section{1. はじめに}

駿河湾に面した静岡清水海岸では，安倍川河道におい て1967年まで行われた大規模な砂利採取により流出土砂 量が激減し，これに伴って北向きの沿岸漂砂とのバラン スが失われ, 侵食域が河口部から北向きに広がっていっ た (宇多, 1997). しかし砂利採取の禁止とともに 1982/1983 年頃から流出土砂量が再び増加し, 過去に著し く侵食されて護岸が波に曝された地先においても再び土 砂の堆積が見られるようになった. 一方, 静岡・清水海 岸では1970年代から始まった激しい侵食への対策として 多数の離岸堤が設置されたが, 離岸堤群の設置区域では 土砂が塊となって北向きに移動し, その移動速度が約 $260 \mathrm{~m} / \mathrm{yr}$ であることが明らかにされた（宇多, 1997).土 砂堆積は「砂の塊」が空間的に移動するという特徴を示 すことから, sand bodyの移動現象として捉えることが可 能であり,このsand bodyは時間経過とともに侵食箇所を 埋めつつ漂砂下手側 (北側) へ移動している.このよう な sand bodyの移動に関し, 宇多ら（2007a）は, 砂の平 衡勾配と海浜勾配との相対的関係から定まる岸沖漂砂と 沿岸漂砂の作用を考慮した芹沢ら（2002）の等深線変化 モデルを用いてその発生機構について検討した。 この研 究では, sand body発生以前の1983 年の海底地形を固定床 で与え, 計算領域の右 (南) 端から $1.0 \times 10 \mathrm{~m}^{3} / \mathrm{yr}$ の土砂 流入（宇多, 1997）を仮定するとともに, 左端には自由

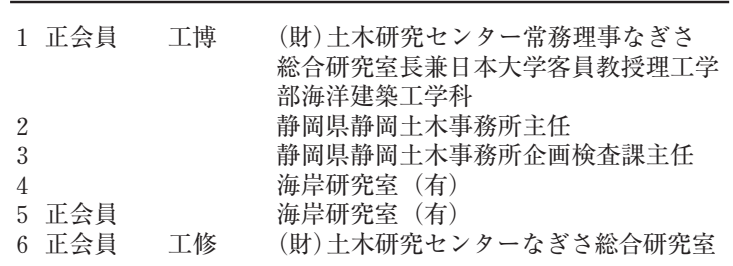

境界を設定することにより sand bodyの移動状況を再現し た. その後, 福濱ら（2008）は, sand bodyは主に砂で構 成されているが, 離岸堤沖では細砂が堆積し, その堆積 域が経年的に東向きに広がったことを実測デー夕より明 らかにした上で, sand bodyと沖の細砂の堆積域の移動を 熊田ら（2007）の粒径を考慮した等深線変化モデルによ り再現した。再現計算では, 南端から細粒・粗粒土砂を それぞれ $7.0 \times 10^{4} \mathrm{~m}^{3} / \mathrm{yr}$ 流入させた. 以上の海浜変形予測 では, いずれも計算範囲を安倍川河口近傍から北向きに ほぼ直線状に伸びた部分とすると同時に, 離岸堤群の設 置区間のみを対象として sand bodyの移動現象の再現を試 みた。しかし漂砂系全体での長期的海浜保全について考 えるには, 漂砂系全体を対象とした上でsand bodyの移動 速度のみなならず, 地形変化までも再現する必要がある. このため本研究では, 海岸の一部を切り出すのではなく, 静岡清水海岸全域を含む漂砂系を対象として長期的地形 変化の再現計算を行い, その上でサンドバイパスなどの 効果について粒径を考慮した等深線変化モデルを用いて 検討した.

\section{2. 実態データの分析}

図-1に示すように, 安倍川河口から三保松原に至る海 岸線は安倍川河口部で突出したあと緩く湾曲し, 清水海

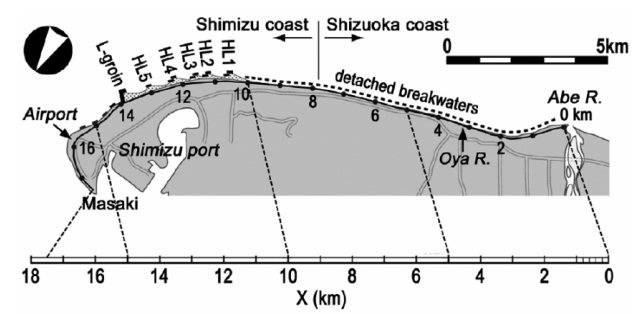

図-1 展開座標系 

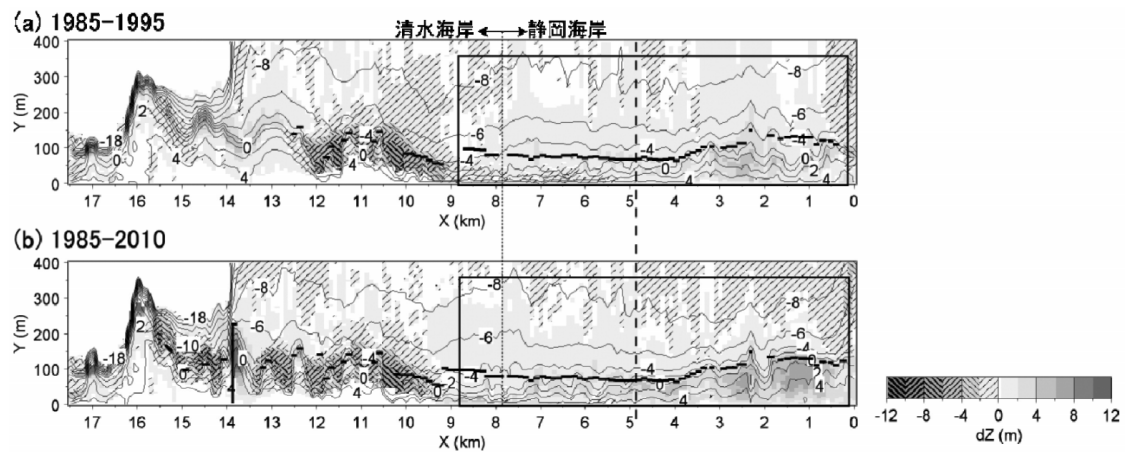

図-2 展開座標系で見た深浅図と 1985年基準の地形変化量の平面分布

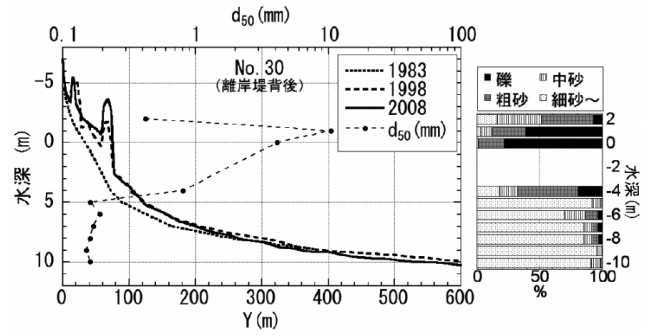

図-3 海浜縦断形と粒度組成の水深方向分布 $(X=4.8 \mathrm{~km}$ (No.30) $)$

岸北部から三保松原砂嘴の先端にかけて海岸線曲率が大 きくなる.このような海岸線形状は砂嘴の発達とともに 長い年月をかけて形成されてきたものなので，本来であ れば砂嘴形成の再現計算を行った上で近年の地形変化を 予測することが理想である。しかし砂嘴形成に至るまで 数千年間の地形変化予測は困難なので, 図-1に示すよう に現況海岸線に沿って座標系を定め，それを直線座標に 展開する手法を用いて海浜変形予測を行うこととし，ま ずこの座標系のもとで実態デー夕の分析を行った。

図-2 は，この展開座標系で求めた 1985 年基準での 1995 年と 2010 年までの地形変化量の分布を示す. 右端には安 倍川が位置しており, 安倍川からの流出土砂が離岸堤群 の背後に堆積しているが, 堆積域は時間経過とともに北 側へと広がっている。これが宇多ら（2007a）や福濱ら (2008）の研究でsand bodyの移動としてその移動状況が 分析されたものである。一方, 離岸堤設置区域の北側の 清水海岸では著しい侵食が生じるとともに侵食域が北側 へと広がり，また $X=14 \mathrm{~km}$ にあるL字突堤の設置ととも にその上手側で集中的な堆砂が生じている.

図-2 の地形変化に対応する縦断形変化と底質粒径調查 （2006年 8 月実施）の結果のうち，一例として図-2に示す $X=4.8 \mathrm{~km}$ 断面での結果を図-3に示す.この断面では- $4 \mathrm{~m}$ 以 浅に粗砂と礫が堆積し, 前浜勾配は約 $1 / 10$ と急である. これに対して $-8 \mathrm{~m}$ 付近は細砂で構成され, 海底勾配も $1 / 100$ と緩やかである. 他の測線でも, 汀線付近から $1 / 10$

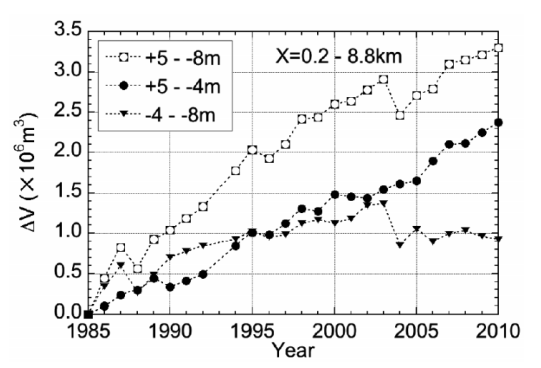

図-4 1985年を基準とした sand bodyの土砂量変化 $(X=0.2 \sim 8.8 \mathrm{~km}$, T.P. $+5 \sim-8 \mathrm{~m})$

と急傾斜で落ち込むものの, 沖合は緩勾配となっている. 次に, 図-2の矩形区域について, 1985年を基準として $Z=+5 \mathrm{~m}$ から $-8 \mathrm{~m}$ の範囲の堆積土砂量を求めた。積分範囲 についてはほぼ-4m以浅では主に礫が堆積し，沖合では 細砂が堆積していることから， $-4 \mathrm{~m}$ 以深と以浅に分けて 土砂量を計算すると，汀線に近い部分に堆積しているほ ぼ礫に相当する土砂量と, 沖合に堆積している細砂の堆 積量が求められる。静岡海岸は過去に侵食され, 侵食対 策として造られた護岸の前面に砂硞が新たに堆積すると いう過程をたどったままた，静岡海岸への土砂供給は安 倍川からであるが，現況で安倍川河口右岸の田尻地区は 護岸と離岸堤で覆われており, 侵食が起こる条件にない ので, 田尻地区からの侵食土砂が河口左岸へと供給され ることはない.このため, 安倍川河口から sand bodyの先 端が到達した場所までの区間における砂礫の堆積は, 安 倍川からの供給によってのみ生じることになり，その総 土砂量の変化より安倍川からの供給土砂量の推定が可能 と考えられる。そこで, 変動の著しい安倍川河口部を除 く $X=0.2 \mathrm{~km}$ から, 2010 年になってようやく sand bodyが到 達し始めた $X=8.8 \mathrm{~km}$ までの間において砂磼の堆積土砂量 の変化を調べた。この場合, 磁と細砂の堆積域の境界の

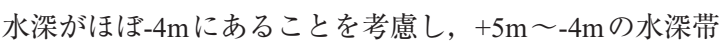
と-4m〜-8m の水深帯に区別して土砂量を求めた．結果 を図-4に示す．これによれば，総土砂量は1985～1995年 の 10 年間で $2.0 \times 10^{6} \mathrm{~m}^{3}$ 増加している. よってこの間での 
表-1 計算条件

\begin{tabular}{|c|c|}
\hline 数值計算手法 & 等深線・粒径変化モデル（熊田ら, 2007） \\
\hline 計算対象範囲 & 静岡海岸・清水海岸：17km \\
\hline 計算期間 & $\begin{array}{l}\text { 1968～2010年（42年間） } \\
\text { 5段階: 1968～1983～1990～1994～1998～} \\
\text { 2010年 }\end{array}$ \\
\hline 初期地形 & $\begin{array}{l}\text { 1968年地形を展開座標でモデル化した } \\
\text { 直線平行等深線 } \\
\text { (海底勾配：-4m以浅 } 1 / 10, \quad-4 \mathrm{~m} \text { 以深 } 1 / 50)\end{array}$ \\
\hline 粒径構成 & $\begin{array}{l}\cdot N=2 \text { 粒径 } \\
\cdot \text { 代表粒径 細粒 } d^{(1)}=0.2 \mathrm{~mm} \text {, 粗粒 } d^{(2)}=2 \mathrm{~mm} \\
\cdot \text { 初期粒径含有率 } \\
\quad+3 \sim 4 \mathrm{~m}: \text { 細粒 } \mu_{1}=0.0, \text { 粗粒 } \mu_{2}=1.0 \\
\quad-5 \sim 7 \mathrm{~m}: \text { 細粒 } \mu_{1}=1.0 \text {, 粗粒 } \mu_{2}=0.0\end{array}$ \\
\hline 平衡勾配 & $\tan \beta_{\mathrm{c}}^{(1)}=1 / 50 \quad($ 細粒 $), \tan \beta_{\mathrm{c}}^{(2)}=1 / 10 \quad$ (粗粒) \\
\hline 交換層の幅 & $\begin{array}{l}\text { 混合層幅 } B=1 \mathrm{~m} （ B=\Delta h / \tan \beta \text { : 混合層厚 } \\
\left.\Delta h=0.03 H_{b} \fallingdotseq 0.1 \mathrm{~m}, \tan \beta=1 / 10\right)\end{array}$ \\
\hline 入射波条件 & $\begin{array}{l}\cdot \text { 砕波波高 } H_{b}=3 \mathrm{~m}, \text { 初期砕波角 } \theta_{w}=7^{\circ} \sim 37^{\circ} \\
\text { 波向分布 } \\
\text {. 安倍川河口 静岡清水海岸境界 } \theta_{w}=7^{\circ} \\
\text {. 静岡清水海岸境界 } \sim 1 \text { 号 } \mathrm{HL} \sim \mathrm{L} \text { 字突堤間 } \\
\theta_{w}=7^{\circ} \sim 17^{\circ} \sim 37^{\circ} \\
\cdot \mathrm{L} \text { 字突堤 } \sim \text { 真崎 } \theta_{w}=37^{\circ}\end{array}$ \\
\hline 潮位条件 & M.S.L. T.P. $+0.0 \mathrm{~m}$ \\
\hline $\begin{array}{l}\text { 限界水深 } \\
\text { バーム高 }\end{array}$ & $\begin{array}{l}\text { 地形変化の限界水深 } h_{C}=7 \mathrm{~m} \\
\text { バーム高 } h_{R}=3 \mathrm{~m}\end{array}$ \\
\hline 漂砂量係数 & $\begin{array}{l}\text { 漂砂量係数内の } A=0.01752 \\
\text { 岸沖・沿岸漂砂量比 } \gamma=0.1 \\
\text { 小笹・ブランプトン項の係数 } \zeta=1.62\end{array}$ \\
\hline $\begin{array}{l}\text { 沿岸・岸沖漂砂 } \\
\text { の水深分布 }\end{array}$ & 宇多・河野の3次式（熊田ら, 2007） \\
\hline $\begin{array}{l}\text { 土砂落ち込みの } \\
\text { 限界勾配 }\end{array}$ & 陸上: $1 / 2$, 水中 : $1 / 2$ \\
\hline 計算等深線範囲 & $z=+3.5 \sim-7.5 \mathrm{~m}$ \\
\hline 計算メッシュ & 沿岸方向 $\Delta X=100 \mathrm{~m}$, 鉛直方向 $\Delta Z=1 \mathrm{~m}$ \\
\hline 計算時間間隔 & $\Delta t=1 \mathrm{hr}$ \\
\hline 境界条件 & 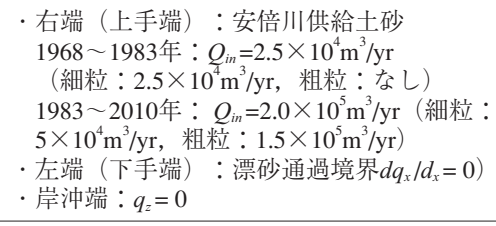 \\
\hline 養浜 & $\begin{array}{l}\text { 養浜箇所・養浜量考慮 (養浜は土砂の湧き } \\
\text { 出しで考慮： }+3 \mathrm{~m} \sim 0 \mathrm{~m} \text { 等深線) } \\
\text { 養浜砂の含有率： } \\
\mu_{1}=0.25 \text { (細粒) }, \mu_{2}=0.75 \text { (粗粒) }\end{array}$ \\
\hline 数值計算法 & 陽解法による差分法 \\
\hline 波浪場の計算法 & 方向分散法, $S_{\max }=25$ \\
\hline その他 & 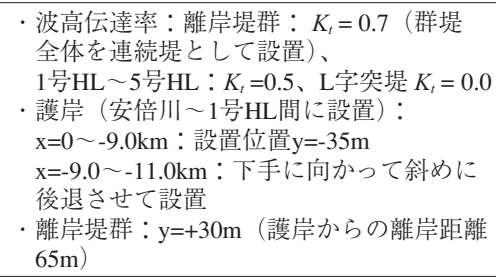 \\
\hline
\end{tabular}

安倍川からの供給土砂量は平均 $2.0 \times 10^{5} \mathrm{~m}^{3} / \mathrm{yr}$ であったと 推定される。またこのうち沖合の-4m以深での土砂増加 割合は $1.0 \times 10^{5} \mathrm{~m}^{3} / \mathrm{yr}$ であって, この付近には細砂が堆積
していることから細砂の供給量の下限值は $1.0 \times 10^{5} \mathrm{~m}^{3} / \mathrm{yr}$ となる。

\section{3. 海浜変形予測}

\section{（1）計算方法}

海浜変形予測には熊田ら（2007）の等深線・粒径変化 モデルを用いた。計算範囲は, 全長 $17 \mathrm{~km}$ の静岡清水海 岸のうち, 安倍川河口からL字突堤までとした。ここに L 字突堤は礫の移動を抑止する一方, 細粒分は沖の海底 谷へ流出している（宇多ら，2007b）ことから, 漂砂境 界とみなすことができる.1968年地形を展開座標でモデ ル化した直線平行等深線を与え, 海底勾配は実測縦断形 を参照して $-4 \mathrm{~m}$ 以浅を $1 / 10,-4 \mathrm{~m}$ 以深を $1 / 50$ とした。波に よる地形変化の限界水深 $h_{C}$ は $7 \mathrm{~m}$, バーム高 $h_{R}$ は $3 \mathrm{~m}$ とし た。また, 粒径は 2 粒径とし, 細粒を $0.2 \mathrm{~mm}$, 粗粒を $2 \mathrm{~mm}$ で代表させ, 初期粒径含有率は $Z=+3 \sim-4 \mathrm{~m}$ では細粒 $\mu_{1}$ が 0 , 粗粒 $\mu_{2}$ が $1.0, Z=-5 \sim-7 \mathrm{~m}$ では細粒 $\mu_{1}$ が 1.0 , 粗 粒 $\mu_{2}$ が 0 とした。平衡勾配は細粒を $1 / 50$, 粗粒を $1 / 10$ と した.

波浪条件としては，当海岸における5\%程度出現頻度 の波 $H_{o}{ }^{\prime}=3 \mathrm{~m} （ \mathrm{~T}=9 \mathrm{~S} ）$ を波向 Sから入射させ, 屈折を考慮 して 1 号 HL付近での砕波角を定めた.この結果と汀線の 方向角の変化を考慮して, 安倍川河口から静岡清水海岸 の境界までは $\theta_{w}=7^{\circ}$, 静岡清水海岸の境界 1 号 $\mathrm{HL} \sim \mathrm{L}$ 字突堤間では $\theta_{w}=7^{\circ} \sim 17^{\circ} \sim 37^{\circ}$ と線形的に変化させた. なお自然状態での沿岸漂砂量 $Q=2.0 \times 10^{4} \mathrm{~m}^{3} / \mathrm{yr}$ で動的安 定状態が満され, 沿岸方向にエネルギーフラックスが一 定に保たれるよう砕波角が大きくなるに従って波高を低 減させた。 また, 図-4に示した静岡海岸の1983年以降の 土砂量変化より, 右 (南) 端では $2.0 \times 10^{5} \mathrm{~m}^{3} / \mathrm{yr}$ の土砂流
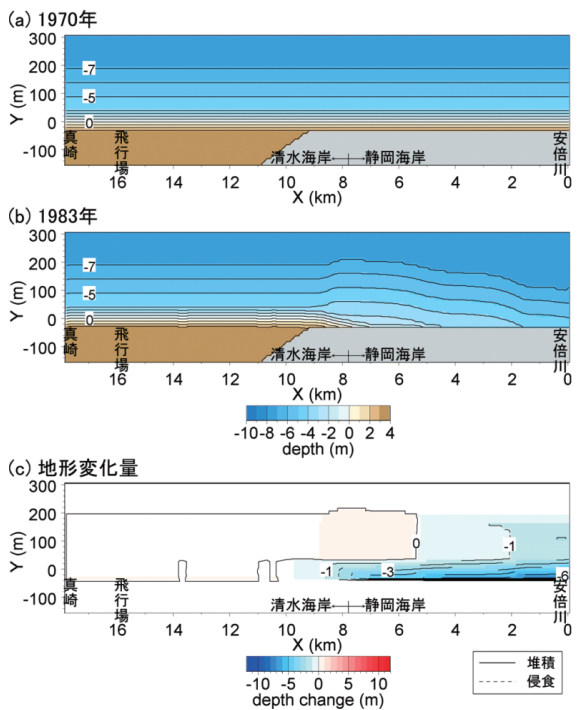

図-5 1983年地形の再現計算結果 


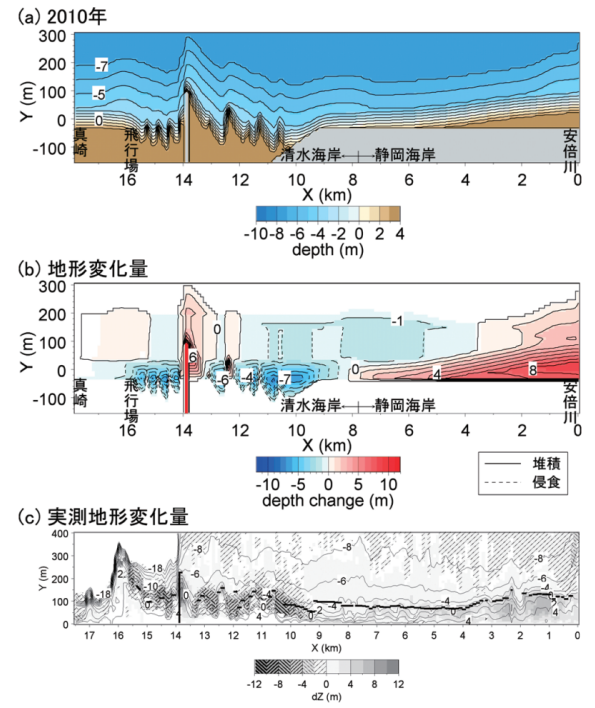

図-6 2010年地形の再現計算結果

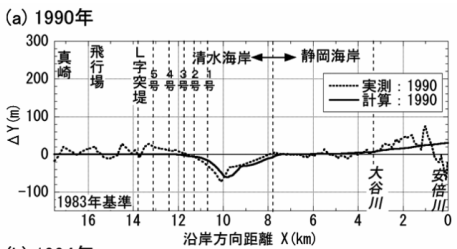

(b) 1994 年
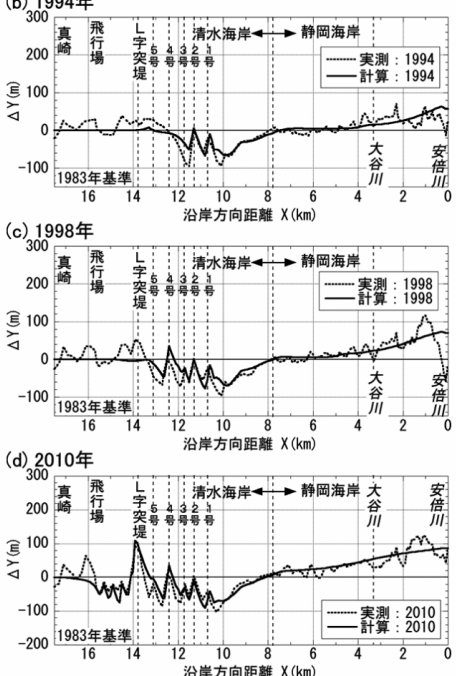

図-7 1983年を基準とした各年の汀線変化量の沿岸方向分布

入とした．また清水海岸では，1989年以降，安倍川河道 の掘削土砂や飛行場付近に堆積した砂砂を用いた養浜が 行われてきているので計算ではそれを考慮した.

\section{(2) 再現計算}

図-5 (a) に示すように1970年当時の海底地形を平行等 深線で与え，波を作用させたときの1983年地形を図-5(b) に，また初期からの地形変化量を図-5 (c) に示す。この 間, 安倍川からの土砂供給量が $2.5 \times 10^{4} \mathrm{~m}^{3} / \mathrm{yr}$ まで激減し
たとしている．土砂供給量と北向きの沿岸漂砂との均衡 が崩れたために安倍川河口側から侵食が始まり，侵食域 が北側へと広がりを示す．同様にして1983年までの計算 結果に打いて安倍川河口から再び $2.0 \times 10^{5} \mathrm{~m}^{3} / \mathrm{yr}$ の土砂供 給が1983年から始まったとして 2010 年までの地形変化 予測を行った。図-6 (a) は地形変化予測の結果を，図-6 （b）は地形変化量を，さらにこれに対応する実測地形変 化量を図-6 (c) に示す．清水海岸で離岸堤群式HLが造 られたため，各HLの上手側では等深線が三角状に前進 し，下手側では楔状に後退している。またL字突堤は規 模が大きいためその上手側に広い堆積域を形成してい る. 安倍川からの流出土砂が離岸堤群の背後を埋めなが ら徐々に北向きに移動しているが, 南部の離岸堤によっ て北向きの沿岸漂砂が抑制されているため離岸堤群の北 側では侵食が進む状況がうまく計算され，予測結果は実 測結果とよく一致している.

図-7は，1983年を基準とした1990～2010年における 計算と実測汀線の比較結果を示す。安倍川からの供給土 砂がsand bodyを形成しつつ北側へ広がっていくために， 安倍川河口付近で汀線が最も前進し，北側に河口から離 れるに従い汀線前進量が小さくなる点や，清水海岸にお いて HL と L字突堤建設に伴うジグザグ形状の汀線変化が 生じる点についても実測と計算結果はよい一致を示す.

\section{4. 将来予測}

\section{（1）現況の養浜を継続}

HL 群周辺で行われてきた養浜について，1998年から 2009 年の実績平均である $5.46 \times 10^{4} \mathrm{~m}^{3} / \mathrm{yr}$ の養浜をそのま ま継続した場合の 20 年後までの地形変化予測の結果を図8に示す. 図-8 (a) は予測地形を, 初期からの地形変量を 図-8（b）に示す．安倍川から供給された土砂が離岸堤群 の背後を北向きに移動し静岡清水海岸の境界付近に至る まで土砂の堆積が進む。しかしその北側の HL 群周辺では 依然として侵食が進むことが分かる．汀線変化と浜幅の 分布 (図-8 (c)，8 (d)) で見ても汀線が前進して浜幅が増 加するのは離岸堤群背後のみであり, 北端の飛行場付近 では汀線後退が続く，浜幅で見ると，静岡海岸南部の大 谷川と安倍川河口間では1983年当時と比べて浜幅の増加 が大きく, 最大 $150 \mathrm{~m} も の$ 浜幅の増加が起こる.この付近 では既設離岸堤が砂啋に埋まるという状態となる。

（2）安倍川からの流出土砂量を増加させた場合

長期的意味から見た安倍川の流出土砂量はほほ $2.0 \times$ $10^{5} \mathrm{~m}^{3} / \mathrm{yr}$ である。したがって現実的にはこの值より大き な供給土砂量を設定することは流域土砂管理の視点から 見れば不合理である。しかし海岸で過去に失われた土砂 量を回復するという意味では自然状態での供給土砂量よ り大きな土砂量を供給することも意味があると考えられ 


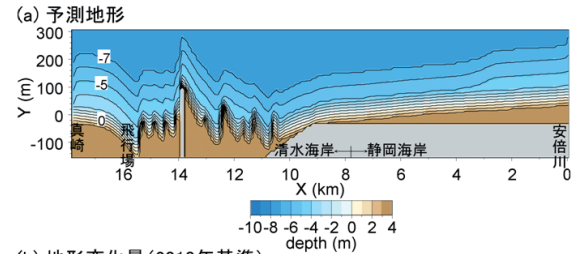

(b) 地形変化量 (2010年基準)

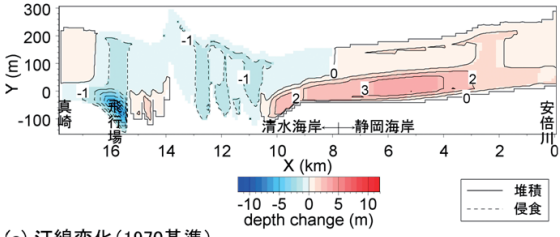

（c）汀線変化 (1970基準
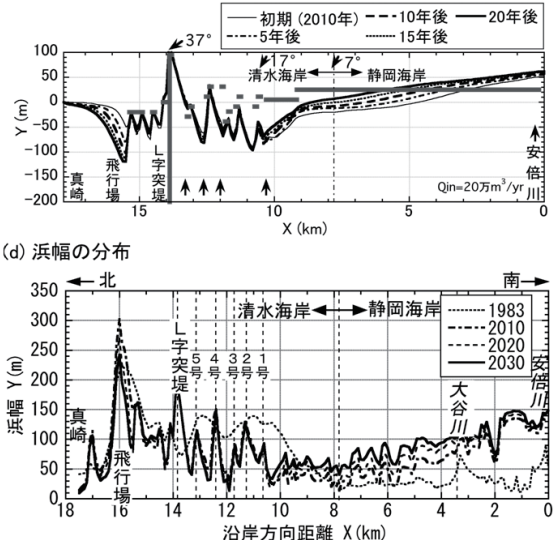

図-8 $5.46 \times 10^{4} \mathrm{~m}^{3} / \mathrm{yr}$ の養浜を継続した場合の地形変化予測 (20年後)

る. そこで安倍川の土砂供給量を $5.0 \times 10^{4} \mathrm{~m}^{3} / \mathrm{yr}$ 増加させ て $2.5 \times 10^{5} \mathrm{~m}^{3} / \mathrm{yr}$ として 20 年後の地形変化予測を行った.

図-9 (a) は予測地形を，初期からの地形変量を図-9 (b) に示す. 安倍川から大量の土砂が流入するため河口の北 側に並んだ離岸堤を埋めるようにして河口デル夕の等深 線が前進する。しかし土砂供給量が増加した効果は河口 周辺域に集中し, HL群がある場所までは効果が及ばな い.この状態は汀線変化を示す図-9 (c) にも明らかであ る.このように安倍川河口から自然状態で流れ込んでい た土砂量よりも大きな土砂量を流入させてもその効果は 河口周辺部に限られ，北部海岸で効果が出るまでには至 らない。この結果は，宇多ら（2008，2009）による天竜 川ダム再編事業に伴い天竜川の流下土砂量を増大させた 場合の計算結果において，供給量を増加させた土砂は河 口周辺部に集中的に堆積するという結果と同じである.

\section{5. 結論}

安倍川からの流下土砂によって形成された静岡清水海 岸の侵食と堆積について, 漂砂系全体を対象として等深 線変化モデルを用いて 1968 年から 2010 年まで 42 年間の 長期的な地形変化の再現計算を行った。この計算では,

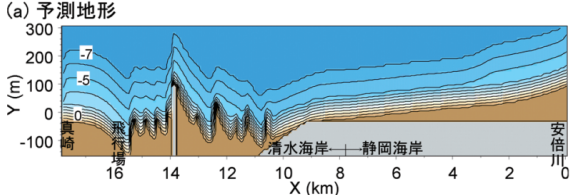

(b) 地形変化量 (2010年基準)

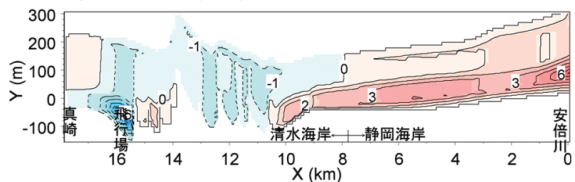

(c) 汀線変化 (1970基準)

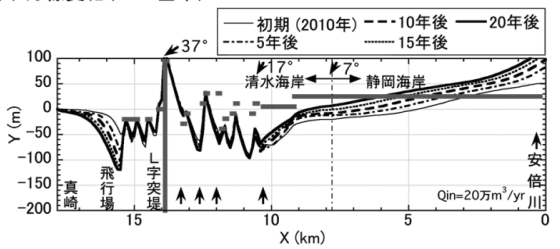

図-9 安倍川流出土砂量を $5 \times 10^{4} \mathrm{~m}^{3} / \mathrm{yr}$ 増加させた場合の地形 変化予測 $(20$ 年後)

sand bodyの移動現象のみならず, 汀線変化, 水樑変化量 の平面分布まで含めた再現計算を行った。これまでの研 究では, sand bodyの発達直前の侵食されきっていた1983 年の海底地形を固定床として与えたが, 本研究では侵食 以前の，自然状態にあった1968年を初期状態とし，それ から2010年までの地形変化の再現を行った．この結果， 計算結果により実測地形変化をうまく説明できた。また 今後 20 年程度の時間スケールにおいては安倍川からの供 給土砂量を増加させても河口から離れた清水海岸の侵 食・堆積とは独立であることも明らかになった。

\section{参 考 文 献}

宇多高明（1997）「日本の海岸侵食」, 山海堂, p. 442.

宇多高明・西谷誠・芹沢真澄・ 三波俊郎・石川仁憲 (2007a)：等深線変化モデルによる sand body移動の数值解 析, 地形, Vol.28, pp.399-414.

宇多高明・吉添高兆・町井 靖 - 西谷 誠・芹沢真澄 - 三波 俊郎・石川仁憲 (2007b)：清水海岸のL字突堤沖におけ る細砂の移動带の形成機構, 海岸工学論文集, 第 54 巻, pp.421-425.

宇多高明 - 長島郁夫 - 古池 鋼 - 宮原志帆 - 石川仁憲 （2008）：天竜川ダム再編事業による流出土砂量の増加が 海岸に及ぼす影響, 海岸工学論文集, 第 55 卷, pp.656-660.

宇多高明 - 古池 鋼 - 宮原志帆 - 芹沢真澄 - 三波俊郎 - 石川 仁憲（2009）：ダム再編事業に伴う天竜川河口デル夕の長 期変形予測, 海岸工学論文集, 第 56 卷, pp.651-655.

熊田貴之・宇多高明・芹沢真澄（2007）：卓越粒径集団に応じ た平衡勾配を考虑した等深線・粒径変化モデル, 土木学会 論文集 B, Vol. 63, No.2, pp.154-167.

芹沢真澄 - 宇多高明 - 三波俊郎 - 古池 鋼 - 熊田貴之 (2002)：海浜縱断形の安定化機構を組み込んだ等深線変 化モデル, 海岸工学論文集, 第 49 卷, 496-500。

福濱方哉・山田浩次 - 宇多高明 - 芹沢真澄・ 三波俊郎 - 石川 仁憲（2008）：静岡海岸における sand bodyの発達と移動お よび沖合での細砂移動の予測, 海岸工学論文集, 第 55 巻, pp.676-680. 